
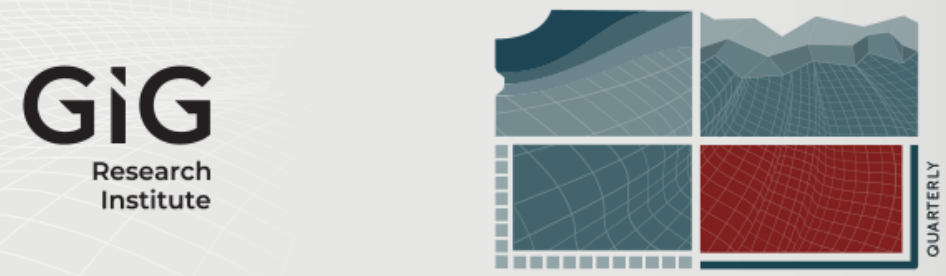

JOURNAL

OF

SUSTAINABLE

MINING

Volume 19 | Issue 3

Article 2

2020

\title{
Exergy life cycle assessment indicators in colombian gold mining sector
}

Author(s) ORCID Identifier:

Natalia A. Cano (iD) 0000-0003-4828-6442

Christian Hasenstab (iD) 0000-0002-5913-4834

Hector I. Velasquez (iD) 0000-0003-2420-2857

Follow this and additional works at: https://jsm.gig.eu/journal-of-sustainable-mining

Part of the Explosives Engineering Commons, Oil, Gas, and Energy Commons, and the Sustainability Commons

\section{Recommended Citation}

Cano, Natalia A.; Hasenstab, Christian; and Velasquez, Hector I. (2020) "Exergy life cycle assessment indicators in colombian gold mining sector," Journal of Sustainable Mining: Vol. 19 : Iss. 3 , Article 2. Available at: https://doi.org/10.46873/2300-3960.1013

This Research Article is brought to you for free and open access by Journal of Sustainable Mining. It has been accepted for inclusion in Journal of Sustainable Mining by an authorized editor of Journal of Sustainable Mining. 


\title{
Exergy life cycle assessment indicators in colombian gold mining sector
}

\begin{abstract}
Thermodynamic methods, such as exergy analysis allow the assessment of environmental load (environmental impacts), by calculating the entropy generated or exergy destroyed due to the use of renewable and non-renewable resources along the entire production chain. In this research, exergy analysis will be approached as an extension of LCA to ExLCA (Exergy Life Cycle Assessment), as complementary tools, for sustainability assessment of two gold mining systems in Colombia: open-pit and alluvial mining. It is quantified exergy life cycle efficiencies; Cumulative Energy/ Exergy Demand, by distinguishing between renewable and non-renewable resources used in the process. The energy contained in renewable and non-renewable resources, interpreted as a measure of its utility potential, and which inefficient use generates waste streams with an exergy content that may be a measure of its potential to cause environmental damage. For open-pit mining $53 \%$ of exergy consumed comes from fossil energy, and $26 \%$ of energetic use of water, while in alluvial mining, $94 \%$ of exergy flow comes from water as a resource used within process activities. In order to reduce the environmental impact associated with gold generation life cycle described in this study, four strategies should be implemented; 1) Increasing efficiency, by reducing the exergy required in tails and extraction stages in open-pit mining process and, casting and molding stage in alluvial mining process, where large exergy supplies are required. 2) Increasing efficiency through the reduction of exergy emissions and residues in casting and molding stage in alluvial mining, and stripping stage in open-pit mining. 3) Using external exergy resources, such as renewable resources from nature (solar, wind, hydraulic). 4) Applying the concept of circular economy, which implies the reduction in consumption of resources.
\end{abstract}

\section{Keywords}

Exergy analysis; Life cycle assessment; Mining process; Gold extraction sustainability

\section{Creative Commons License}

\section{(c) (i)}

This work is licensed under a Creative Commons Attribution 4.0 License. 


\title{
Exergy life cycle assessment indicators in Colombian gold mining sector
}

\author{
Natalia A. Cano*, Christian Hasenstab, Héctor I. Velásquez \\ Universidad Nacional de Colombia Sede Medellín, Medellín, 050041, Colombia
}

\begin{abstract}
Thermodynamic methods, such as exergy analysis allow the assessment of environmental load (environmental impacts), by calculating the entropy generated or exergy destroyed due to the use of renewable and non-renewable resources along the entire production chain. In this research, exergy analysis will be approached as an extension of LCA to ExLCA (Exergy Life Cycle Assessment), as complementary tools, for sustainability assessment of two gold mining systems in Colombia: open-pit and alluvial mining. It is quantified exergy life cycle efficiencies; Cumulative Energy/ Exergy Demand, by distinguishing between renewable and non-renewable resources used in the process.

The energy contained in renewable and non-renewable resources, interpreted as a measure of its utility potential, and which inefficient use generates waste streams with an exergy content that may be a measure of its potential to cause environmental damage. For open-pit mining $53 \%$ of exergy consumed comes from fossil energy, and $26 \%$ of energetic use of water, while in alluvial mining, $94 \%$ of exergy flow comes from water as a resource used within process activities.

In order to reduce the environmental impact associated with gold generation life cycle described in this study, four strategies should be implemented; 1) Increasing efficiency, by reducing the exergy required in tails and extraction stages in open-pit mining process and, casting and molding stage in alluvial mining process, where large exergy supplies are required. 2) Increasing efficiency through the reduction of exergy emissions and residues in casting and molding stage in alluvial mining, and stripping stage in open-pit mining. 3) Using external exergy resources, such as renewable resources from nature (solar, wind, hydraulic). 4) Applying the concept of circular economy, which implies the reduction in consumption of resources.
\end{abstract}

Keywords: exergy analysis, life cycle assessment, mining process, gold extraction sustainability

\section{Introduction}

$\mathrm{T}$ he growing demand in the consumption of goods and services translates into the increase of extraction and production of primary metals, since the availability and access to these resources are fundamental conditions to guarantee human welfare and global economies functioning [1,2]. Despite the great efforts of society in relation to the efficient use of resources, circular economy and dematerialization itself, defined as the reduction in the amount of energy and materials required for some economic function [3], with the objective of reducing environmental impacts and maximizing the use of renewable resources (Eco-efficiency) [4].

Mining sector, minerals processing, and metals production, like other industrial sectors, are under increasing pressure to reduce, not only the renewable, non-renewable, and energy sources they consume, but also the waste released into the air, soil, and water. From there, to materialize the concept of sustainability in different production systems, sustainable energy resources, and the efficient use of their waste are required [5]. Despite deep debates and conceptual ambiguities, which have not allowed the establishment of a universally

Received 30 November 2019; revised 23 February 2020; accepted 25 February 2020.

Available online 28 September 2020.

* Corresponding author.

E-mail addresses: nacanol@unal.edu.co (N.A. Cano), chasenstab@unal.edu.co (C. Hasenstab), hivelasq@unal.edu.co (H.I. Velásquez). 
accepted definition by the scientific community [6], far from being agreed on how to assess mining sustainability, and even within similar contexts and analysis units [7]. Being the main debate, whether the total capital stock should be kept constant in monetary terms (weak sustainability) or in physical terms (strong sustainability) in order to meet the needs of the present without compromising the ability of future generations to supply their own needs [8].

The mining sector is at a crossroads of one sustainable development challenges: sustainable mining industrial practices [9]. Despite the fact that many NGOs have argued that "mining is intrinsically unsustainable" and that a truly sustainable society will take less mineral from land each year [10]; contrary to what the International Council on Mining and Metals (ICMM) holds, "mining activities should be kept to a minimum, since the sector plays an important role in promoting sustainable development" [1], Life Cycle Assessment (LCA) has been accepted by the European waste policy as a useful tool to measure the impact of products and services on the environment, either through raw materials and resources consumption, or for environmental deterioration caused by pollutant emissions, which take place on each life cycle stage, which leads to sustainable use of resources [11]. The unique feature of LCA is the focus on a life-cycle perspective (Goran [12]. This implies that system limits are so wide that they allow accounting for resources that enter the system from nature and emissions that are released into the environment. However, the literature review shows a limited number of published mining LCA studies, which may be due to the lack of life cycle thinking in the industry [13].

Similarly, there are thermodynamic methods, which allow the assessment of environmental load, by calculating the entropy generated, or the exergy destroyed by a process (a method based on exergy decrease or entropy increase) (Goran [12] because environmental degradation is a problem associated, among others, with exergy losses (destruction and disposal) $[14,15]$. Methods and data, which are based on this approach, have been developed for LCA as an environmental impact category [16]; [17]; [18]; Göran [19]; [20]. The ultimate goal is to preserve exergy through greater efficiency. It is, in other words, to degrade as little exergy as possible for a process. In this way, the environmental damage is reduced. Waste exergy emissions are another relevant point since the exergy contained in waste/emissions contains energy available that, since it is not in equilibrium with the environment, generally has the potential to damage it. Only a few times can this change be perceived as beneficial [5].

On the one hand, Life Cycle Assessment limits the environmental impacts in three great perspectives: damage to ecosystem, quality, and damage to human health [21]. Its generalization and impact weighting (weight), or comparison of these aggregations is difficult because it is often limited to very specific contexts, which makes it become a complex and controversial issue in the scientific community [22]. On the other hand, Exergy Analysis allows to cover these deficiencies by means of accounting the destroyed exergy as one of the negative effects related to resources demand. However, its application also has technical and theoretical restraints regarding the evaluation of sustainability [23]. In relation to the application of Exergy Analysis for mineral resources valuation, it can also measure physical facts related to the composition, concentration, or cohesion of minerals. However, it is unable to quantify social aspects or certain environmental aspects, which are also crucial in the mining industry [24] [25].

For the above reasons, several studies propose to incorporate "Exergy Life Cycle Assessment" (ExLCA) with the objective of expanding the limits of traditional exergy analysis and thus, explain the energy quality incorporated in products as a complementary analysis [25]; [26]; [27]. Also, to evaluate and to improve the thermodynamic performance of productive systems, by reducing energy resources depletion [28], renewable and non-renewable, throughout their life cycle. That is, exergy analysis can be part of LCA, by representing a method for Life-Cycle Impact Assessment (LCIA) of the resource [17]. It should be clarified that ExLCA is complementary information, and it is not exchangeable with conventional LCA because environmental impacts of LCA cannot be reduced to a single exergy value [29]; [26]; [28], who consider that LCA provides more information than the obtained/reduced with exergy.

In spite that exergy data on mineral resources available in the literature are inadequate to apply to exergy life cycle analysis, due to incompleteness, inconsistencies, and a dated thermochemical basis [30], in this research, Exergy Analysis will be addressed as indicator of the energy quality of resources, as an extension of LCA to ExLCA for the assessment of sustainability of two gold mining systems in Colombia: open pit and alluvial mining, from cradle to gate. Exergy Analysis methods taken from a life-cycle perspective, quantifying life cycle exergy efficiencies; Cumulated Exergy Demand 
(CExD) [17] and Cumulative Energy Demand (CEnD) indicators [31] of open-pit and alluvial gold mining system from cradle to gate taken from Ecoinvent 3.1 database. Both indicators quantify energy and exergy used throughout gold life cycle, by distinguishing between renewable and nonrenewable energy requirements. Alluvial mining, globally-speaking, is a less conventional extractive method, which may be why no ExLCA has previously been attempted for the determination of CExD and CEnD for comparative sustainability assessment of alluvial and open-pit gold mining.

\section{Case study description}

The exploitation of gold in Colombia has two types of deposits based on geological conditions of formation. Primary deposits, characterized by underground exploitation (mineral deposits in situ, where initial exploitation takes place in surface areas and then in depth) [32]; and secondary or alluvial deposits with open sky exploitation (those that after weathering processes of a primary reservoir, have a natural mechanical disintegration and gold particles are transported at certain distances by the action of water, they tend to concentrate in water channels, giving rise to the known "gold placer" [33]; [32]. $18 \%$ of gold production in Colombia comes from reef farms and $82 \%$, from alluvial operations.

In this research, two types of extractive technologies will be addressed as a case study: Open-pit and alluvial mining technology for the exploitation of a primary and secondary deposit, respectively [34]. Table 1 describes input and output flows of the two studied systems shown in Fig. 1 and 2.

\subsection{Open-pit mine description}

The case study open-pit mine is designed for gold production, but silver is a by-product [35]; Cano [34] as it explained in the Fig. 1. In preparation for mining, approximately 58 hectares of vegetation and soil are stripped, in an average year, with the soil stored for restoration work, which is undertaken as the mined area advances. The ore extraction operations employ conventional drilling, blasting, loading, and hauling, which include excavation with hydraulic shovels.

Following extraction, the ore undergoes a primary crushing process. $78 \%$ of the particles from primary crushing go to primary and secondary wet milling, in order to further reduce their size. Water is sprayed in order to control emissions of total particulate matter during crushing and milling.
The milled ore passes to a flotation process. Foaming and organic agents are added in order to promote the flotation of the gold-containing sulfidic minerals and the retention of other minerals. The flotation concentrate is classified by hydrocyclones, out of which fine material (overflow) goes to the leach circuit, and coarse material (underflow), feeds milling and gravity concentration circuits. The wastes are pumped to the tailings dam at $66 \%$ moisture content. This flotation process is designed to recover $96 \%$ of all gold present in the ore and $80 \%$ of all silver. Gravity separation, which uses two vertical mills is applied to separate the coarser fraction of the flotation concentrate. $34.7 \%$ of gold and $10.0 \%$ of silver of the input to the gravity separation is recovered as gravity concentrate. The gravity concentrate is sent to the leaching reactor.

In the leach tanks, sodium hydroxide is added for $\mathrm{pH}$ conditioning and sodium cyanide is added to dissolve the gold. The mixture is mechanically agitated. Two streams are obtained: a gold and silver pulp; and waste tails. The pulp from leaching feeds the carbon-in-pulp (CIP) circuit, wherein the gold and silver are adsorped onto activated carbon. Once the activated carbon has reached the required gold and silver content, it goes to the CIP elution circuit. Sodium hydroxide $(\mathrm{NaOH})$ and sodium cyanide $(\mathrm{NaCN})$ are injected into the elution column in order to release gold and silver from the carbon. The resulting elution goes to the electro-winning process in order to selectively precipitate gold and silver, which is sent to the casting furnace.

Sterile carbon (carbon uncharged of gold), which results from the elution process, is sent to carbon reversing furnace in order to reactivate it and reuse it in the CIP process. In the leaching step, along with carbon adsorption, elution, and electrowinning process, gold recovery is $97 \%$ and silver recovery is $65 \%$.

Flotation tails correspond to $96.5 \%$ of the total industrial wastewater, which is generated in the separation process. These require no special chemical treatment prior to the disposal in the tailing ponds. Leaching tails and CIP wastes correspond to the remaining $3.5 \%$, which prior to disposal in the tailings, are treated, by using hydrogen peroxide (H2O2). Gold and silver are recovered, by using a heat-based pyrometallurgical process.

\subsection{Alluvial mining description}

In the case study, gold is mined from alluvial deposits of flood plain. Gold is associated mainly with gravel and sand layers of flood plains, as it is explained in Fig. 4. The progress of mining is based 
Table 1. Input/output description in open-pit and alluvial mining technology.

\begin{tabular}{|c|c|c|c|}
\hline & Open-pit Mining Technology & Alluvial (or placer) Mining Technology & Unit \\
\hline \multicolumn{4}{|l|}{ Input } \\
\hline Water & ${ }^{1} 5.70, \mathrm{E}+07$ & to $9.79, \mathrm{E}+07$ & ton/year \\
\hline Energy (electrical) & ${ }^{m} 2,03 E+12$ & b $2.53 \mathrm{E}+11$ & $\mathrm{~kJ} /$ year \\
\hline Energy (gas) & ${ }^{\mathrm{n}} 1.68, \mathrm{E}+10$ & ${ }^{\mathrm{c}} 1,60 \mathrm{E}+07$ & $\mathrm{~kJ} /$ year \\
\hline Energy (diesel) & or $1,15 \mathrm{E}+12$ & ${ }^{d} 1,12 E+09$ & $\mathrm{~kJ} /$ year \\
\hline Oxygen (air) & $\mathrm{p} 3.75, \mathrm{E}+05$ & e 40 & ton/year \\
\hline Others & $* * 1.01, \mathrm{E}+06$ & * 318.8 & ton/year \\
\hline \multicolumn{4}{|l|}{ Output } \\
\hline Inert material removed (sterile mineral) & ${ }^{\mathrm{q}} 6.94, \mathrm{E}+07$ & ${ }^{\mathrm{f}} 1.06, \mathrm{E}+08$ & ton/year \\
\hline Vegetation cover harbors (clearing and stripping) & ${ }^{\mathrm{r}} 1.33, \mathrm{E}+03$ & g 60 & ton/year \\
\hline Sludge tails (wet weight) & ${ }^{\mathrm{s}} 2.42, \mathrm{E}+07$ & ${ }^{h} 4.52, E+03$ & ton/year \\
\hline Energy losses & ${ }^{\mathrm{t}} 1,24, \mathrm{E}+12$ & ${ }^{\mathrm{i}} 4.74, \mathrm{E}+10$ & $\mathrm{~kJ} /$ year \\
\hline $\begin{array}{l}\text { Emissions of substances to air, water and soil by } \\
\text { combustion, detonation, trituration " leakage etc. }\end{array}$ & - & & \\
\hline Stored material containing mineral of interest & ${ }^{v} 3.98, E+07$ & - & ton/year \\
\hline Ferrous Metal co-product (dry weight, $55 \%$ iron) & - & 1.55 & ton/year \\
\hline Silver co-product (dry weight) & ${ }^{\mathrm{w}} 21.55$ & - & ton/year \\
\hline Gold (dry weight) & ${ }^{x} 19.05$ & ${ }^{\mathrm{j}} 3.10$ & ton/year \\
\hline \multicolumn{4}{|l|}{ Recycling } \\
\hline Water & ${ }^{\mathrm{y}} 4.79, \mathrm{E}+07$ & ${ }^{\mathrm{k}} 4.42, \mathrm{E}+05$ & ton/year \\
\hline
\end{tabular}

${ }^{a}$ Water in alluvial mining technology (ton/year): Exploration (1.25, E + 02), clearing and stripping (1.15, $\left.\mathrm{E}+06\right)$, float up of the suction dredger (1.00, E + 07), mechanical screening (7.46, E + 07), hydraulic jigs (1.12, E + 07), sluice boxes (4.84, E + 05), physical separation (4.46, E + 05), Waste Tailings Treatment Plant (3.80, E-01), Services (9.38, E + 03 water for domestic use, not used into the operational process).

${ }^{\mathrm{b}}$ Electrical energy in alluvial mining technology (kJ/year): clearing and stripping $(9,98, \mathrm{E}+10)$, dipper dredger $(6,86, \mathrm{E}+10)$, mechanical screening $(4,47, \mathrm{E}+10)$, hydraulic jigs $(2,33, \mathrm{E}+10)$, sluice boxes $(2.76, \mathrm{E}+09)$, physical separation $(1.92, \mathrm{E}+08)$, filtration-separation (7.67, E + 07), chemical separation $(1,15, \mathrm{E}+08)$, WTTP $(4.77, \mathrm{E}+07)$, tailing pond $(6.95, \mathrm{E}+07)$, services $(1.35$, E +10 to support suction dredger, dipper dredger and administrative offices).

${ }^{\mathrm{c}}$ Gas energy (propane) in alluvial mining technology (kJ/year): drying and separation of ferrous minerals $(1.60, \mathrm{E}+07)$.

${ }^{\mathrm{d}}$ Diesel fuel (derived from petroleum) in alluvial mining technology (kJ/year): Exploration (2.86, E + 08), Casting and molding (4.33, $\mathrm{E}+06)$, Services $(8.34, \mathrm{E}+08$ to support suction dredger, dipper dredger).

e Oxygen (air) in alluvial mining technology (ton/year): drying and separation (20), tailing pond (20).

${ }^{\mathrm{f}}$ Inert material removed (sterile mineral in dry weight) in alluvial mining technology (ton/year): reserves evaluation, exploration (5.61, $\mathrm{E}+02)$; reserves evaluation, clearing and stripping (3.65, $\mathrm{E}+07)$; mineral extraction, dipper dredger $(6.95$, E +07$)$.

${ }^{\mathrm{g}}$ Vegetation covered harbors in alluvial mining technology (ton/year): clearing and stripping (60 corresponding to 140 hectares).

h Sludge tails (wet weight) in alluvial mining technology $4.52, \mathrm{E}+03$ with $98.7 \%$ humidity.

${ }^{\mathrm{i}}$ Energy losses in alluvial mining technology (KJ/year): clearing and stripping $(9,98, \mathrm{E}+09)$, dipper dredger $(6,86, \mathrm{E}+09)$, mechanical screening (2,41, E + 10), hydraulic jigs (2, 33, E + 09), sluice boxes (7.73, E + 08), physical separation (1.92, E + 07), filtration-separation (2.15, E + 07), chemical separation (3, 22, E + 07), WTTP (1.34, E + 07), tailing pond (1.94, E + 07), services (3.10, E + 09 to support suction dredger, dipper dredger and administrative offices), drying and separation of ferrous minerals (1.60, $\mathrm{E}+06$ ), Exploration (1.80, $\mathrm{E}+08$ ), Casting and molding (1.99, $\mathrm{E}+03)$.

${ }^{\mathrm{j}}$ Gold (dry weight) in alluvial mining technology (ingot/year): 155 each $20 \mathrm{~kg}$.

${ }^{\mathrm{k}}$ Recycling in alluvial mining technology, water treated from WTTP to physical separation.

${ }^{1}$ Water in open-pit mining technology (ton/year): clearing and stripping (5.65, E + 06 water for irrigation to minimize PST in the air), mineral excavation (5.08, E +0606 spray irrigation systems to minimize PST in the air), secondary milling (3.59, E +07$)$, gravimetric separation $(8.32, \mathrm{E}+06)$, floatation $(2.08, \mathrm{E}+06)$, elution $(6.96, \mathrm{E}+05)$. Primary crushing step is not significant for irrigation systems, which is not quantified into the process.

* Others in alluvial mining technology (ton/year): services (7.3 organic material in domestic wastewater), chemical separation (emulsifying agent 0.1 , foaming agent 0.23 , flotation agent 0.48 ), WTTP (coagulating agent 0,45 ), Casting and molding (Sodium borate 232.68 a fluxing agent, calcium carbonate 77.56).

${ }^{m}$ Electrical energy in open-pit mining technology (kJ/year): mineral excavation $(8.08, \mathrm{E}+10)$, primary crushing $(7.82, \mathrm{E}+10)$, secondary milling (1.36, $\mathrm{E}+12)$, gravimetric separation $(2,15, \mathrm{E}+09)$, floatation $(1,97, \mathrm{E}+11)$, leaching $(4,45, \mathrm{E}+10)$, carbon adsorption $(8,05$, $\mathrm{E}+09)$, detoxification $(2,02, \mathrm{E}+08)$, tailing pond $(5,34, \mathrm{E}+10)$, elution and carbon regeneration $(3,90, \mathrm{E}+10)$, casting and electrowinning $(7,99, \mathrm{E}+09)$, other services (1.55, E + 11 administrative offices, public services).

${ }^{\mathrm{n}}$ Gas energy (liquefied petroleum gas) in open-pit mining technology (kJ/year): other services $(1.68, \mathrm{E}+10)$.

${ }^{\circ}$ Diesel fuel (derived from petroleum) in open-pit mining technology (kJ/year): mineral excavation $(1,14, \mathrm{E}+12)$, casting and electrowinning (1,35, E + 09), other services (5,35, E + 09 lightweight vehicles).

${ }^{\mathrm{p}}$ Oxygen (air) in open-pit mining technology (ton/year): floatation $(2.27, \mathrm{E}+04)$, leaching $(3.75, \mathrm{E}+05)$.

${ }^{\mathrm{q}}$ Inert materials removed (in mineral sterile dry weight) in open-pit mining technology (ton/year): reserves evaluation, clearing and stripping (1.09, E + 03); mineral excavation (6.93, E + 07).

${ }^{\mathrm{r}}$ Vegetation covered harbors in open-pit mining technology (ton/year): clearing and stripping (1.33, $\mathrm{E}+03$ vegetation covered harbors).

${ }^{\mathrm{s}}$ Sludge tails (wet weight) in open-pit mining technology (ton/year): $2.42, \mathrm{E}+07$ with $2.36, \mathrm{E}-04 \%$ humidity. 


\begin{abstract}
${ }^{\mathrm{t}}$ Energy losses open-pit mining technology (KJ/year): mineral excavation (7,48, E + 11), primary crushing $(1,49, \mathrm{E}+10)$, secondary milling (2,59, $\mathrm{E}+11)$, gravimetric separation (2.15, $\mathrm{E}+08)$, floatation $(5.50, \mathrm{E}+10)$, leaching $(4.45, \mathrm{E}+09)$, carbon adsorption $(3.62$, $\mathrm{E}+09)$, detoxification $(5,64, \mathrm{E}+07)$, tailing pond $(5,34, \mathrm{E}+09)$, elution and carbon regeneration $(1,09, \mathrm{E}+10)$, casting and electrowinning (1,65, E + 09), other services (1.39, E + 11 administrative offices, public services).

u Emissions, Total Suspended Particles (PST) in open-pit mining technology (ton/year): mineral excavation (1.75, E +03$)$, primary crushing (2.41, E + 01), secondary milling $(7,09, \mathrm{E}+01)$, tailing pond $(3.75, \mathrm{E}+02)$.

${ }^{v}$ Stored material containing mineral of interest (ton/year): $55 \%$ of the extracted material $(3.98, \mathrm{E}+07)$ with a significant gold concentration is stored $(3.98, \mathrm{E}+07)$ for beneficiation in the future when mine is reaching its end of life.

${ }^{\mathrm{w}}$ Silver (dry weight) in open-pit mining technology (ingot/year): Average 1078 each $20 \mathrm{~kg}$.

${ }^{x}$ Gold (dry weight) in open-pit mining technology (ingot/year): Average 952 each $20 \mathrm{~kg}$.

${ }^{\mathrm{y}}$ Recycling in open-pit mining technology, water treatment from WTTP to all the process.

** Others in open-pit mining technology (ton/year): mineral excavation (1.41, E + 04 Ammonium Nitrate - Fuel Oil ANFO, 95\% ammonium nitrate and 5\% kerosene), chemical separation (1.08, E + $01 \mathrm{NaOH} ; 8.99, \mathrm{E}+01 \mathrm{NaCN})$, floatation (Potassium Ammonium Xanthate 5.29, $\mathrm{E}+02,4.37, \mathrm{E}+02$ flotation agent), leaching $(1.87, \mathrm{E}+03 \mathrm{NaCN}, 2.19, \mathrm{E}+03 \mathrm{CaO})$, carbon adsorption $(2.67, \mathrm{E}+03$ activated carbon), detoxification $\left(1.15, \mathrm{E}+02 \mathrm{CaO}, 1.10, \mathrm{E}+00 \mathrm{H}_{2} \mathrm{O}_{2}, 1.27, \mathrm{E}+02 \mathrm{Na}_{2} \mathrm{~S}_{2} \mathrm{O}_{5}\right)$, tailing pond (flocculating agent 3,11, $\mathrm{E}+02)$, elution and carbon regeneration $(9,91, \mathrm{E}+05$ inorganic chemicals).
\end{abstract}

on the results of exploration drilling. Prior to mining, typically, 133 hectares of land are cleared for mining every year. This equates to 60 tons of vegetation per year, which is stored and biodegraded for later use in land restoration [35]; [34].

Extraction first requires the use of suction dredgers, which remove superficial sands, clays, and silts. These are deposited in previously mined areas according to the cut and fill method. A dipper dredge advances behind the suction dredge, by removing deeper gravels and sands. Gold separation uses gravimetric concentration on board the dipper dredger, based on the high specific gravity of gold compared with barren (economically useless) rock. Material from the exploration stage, which contains a significant amount of gold, is added to the gravimetric process.

The gravimetric separation recovers $96 \%$ of mined gold. The recovered gold is passed directly to a drying step and separation of ferrous minerals as byproducts. The material containing the remaining $4 \%$ of gold is passed to flotation. This method involves the use of foamers and $\mathrm{pH}$ adjustment to promote flotation of the particles, which are high in gold content. Between $92 \%$ and $99 \%$ of the gold passed to flotation, is recovered.

Waste from the separation process is passed through the sedimentation plant, which aims to recover $99 \%$ of wastewater. Dewatered tailings are disposed of in the tailings ponds. Gold obtained from concentrates is melted in a tilting dieselmelting furnace.

\section{Methodology}

As mentioned above, the objective of this research is to assess and to compare the sustainability of the open-pit and alluvial mining technologies in Colombia through exergy indicators. Life Cycle Exergy Assessment (LCEA) from cradle to gate, Ecoinvent 3.1 database and $1 \mathrm{~kg}$ of gold as Functional Unit (FU), was carried out in order to quantify Energy Life Cycle and exergy demand of the extractive process. Inventory data were supplied by the two mining companies on an annual time scale. The alluvial mine company provided 6 years of data (2012-2018) based on the mine's inventory of materials and energy. The open-pit mine company provided 11 years of data based on modelling of planned operations [36].). On the one hand, $\mathrm{Cu}$ mulative Exergy Demand (CExD) is defined as the sum of exergy of all resources required in order to provide a process or a product [31]; [17]. On the other hand, Cumulative Energy Demand (CEnD) is defined as the sum of the total primary energy required, in order to provide a process or a product [15]. Sensitivity analysis is to be used in order to assess CEnD and CExD categories, by assuming an improved efficiency in electricity (CFE) and fuel (diesel) (CFD) up to $30 \%$.

The objective of Cumulative Energy Demand Indicator (CEnD) is to quantify the energy used throughout gold life cycle, by distinguishing between renewable and non-renewable energy requirements. CEnD-indicator is split up into eight categories and expressed in MJ equivalents, as shown in Table 2.

Cumulative Exergy Demand indicator (CExD) is introduced to depict total exergy removal from nature in order to provide a product, by summing up the exergy of all resources required. CExD assesses the quality of energy demand, and it includes the exergy of energy carriers, as well as non-energetic materials [31]. Similar to CEnD, this indicator as 


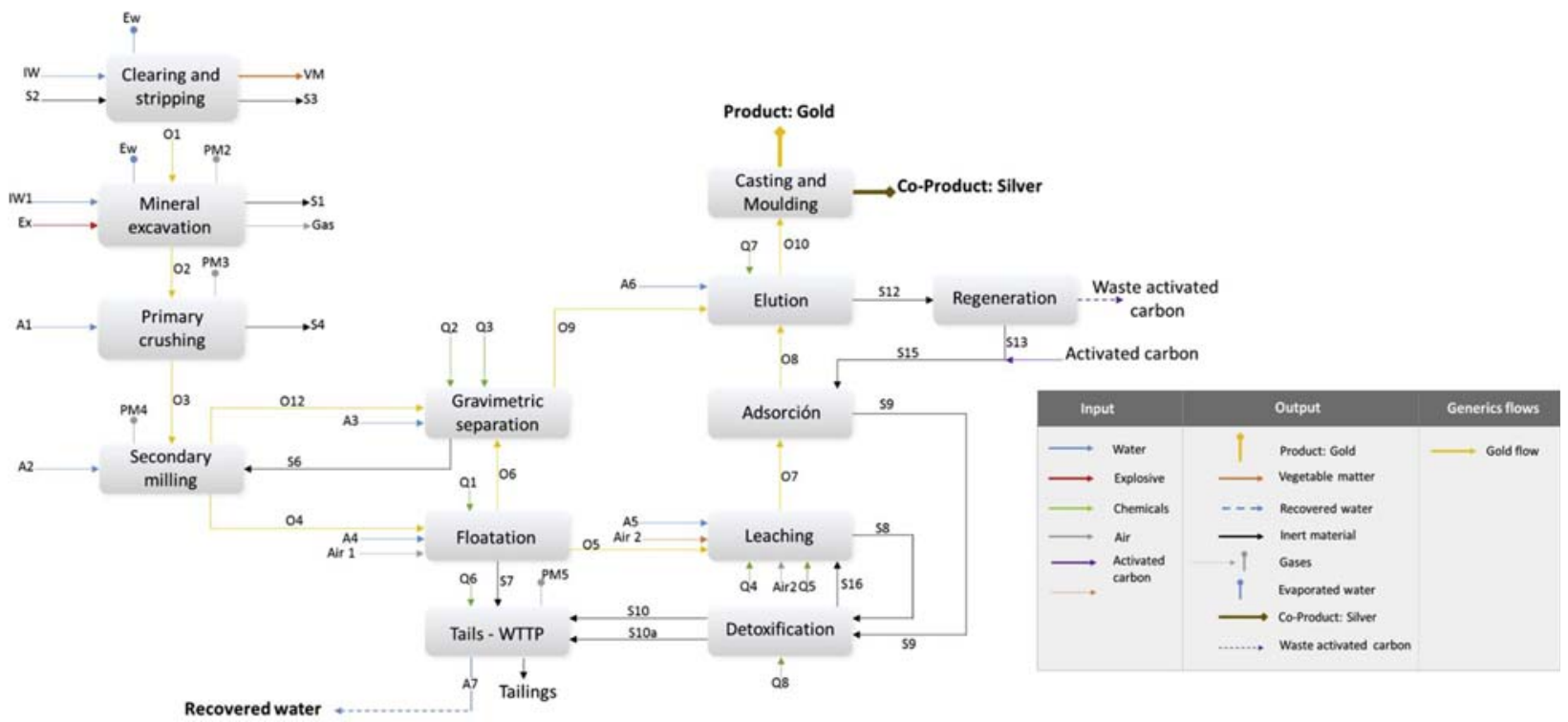

Fig. 1. Description of open-pit mining technology.

well is split up into eight categories and expressed in MJ equivalents, as shown in Table 3 . There is no impact category for geothermal energy because no characterization is assigned to 'Energy, geothermal' since this elementary flow is mainly input in order to heat pump systems. It was assumed that the average temperature of heat sources for heat pumps is below the temperature in reference to the environment $(298.15 \mathrm{~K})$, which is applied for calculating characterization factors [17]; [37].

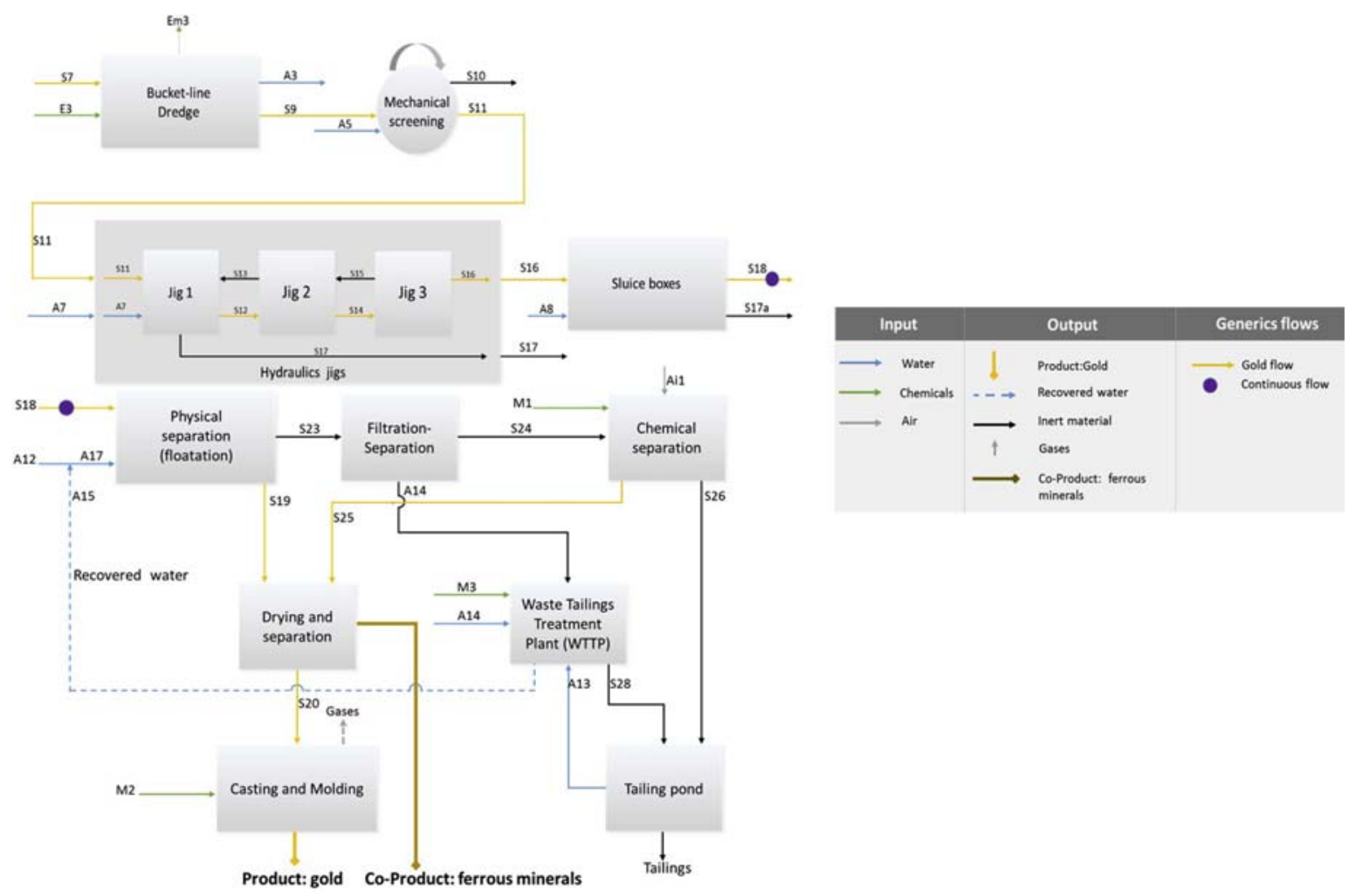

Fig. 2. Description of alluvial mining technology. Note: Exploration and stripping is not graphed because is a batch process, but are into account in the calculated. 


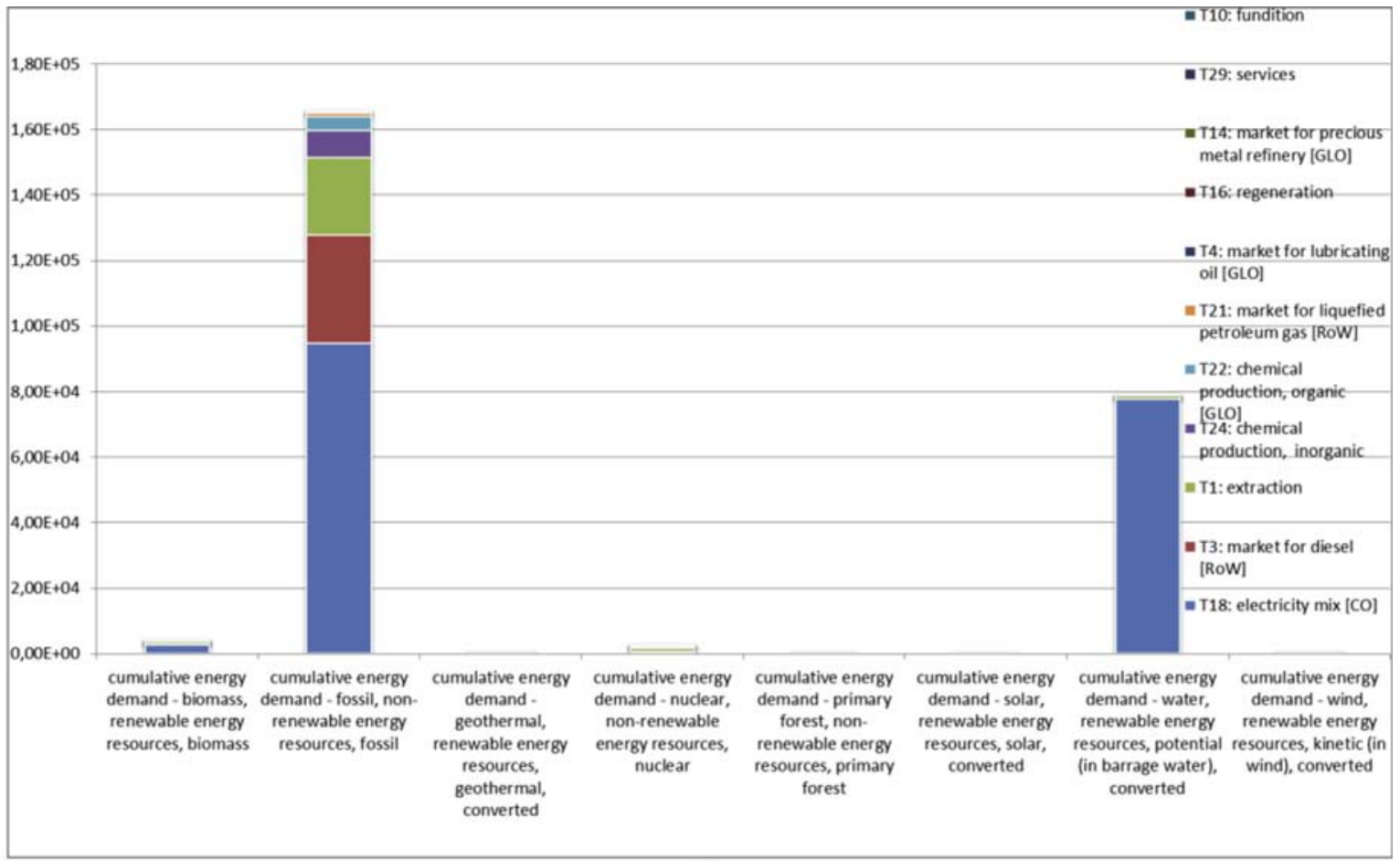

a)

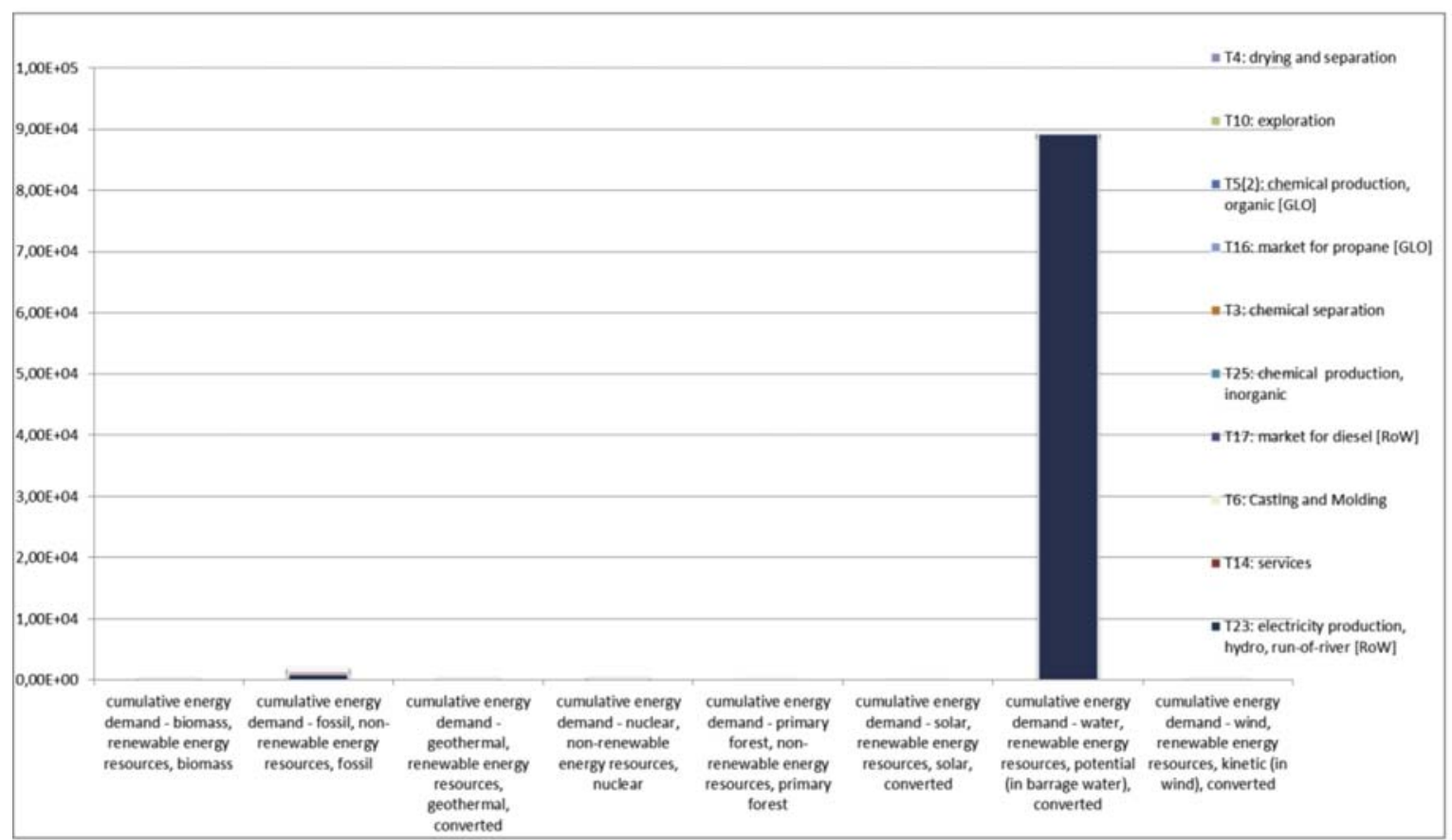

b)

Fig. 3. Cumulative Energy Demand (CEnD) for each stage of a) open-pit mining process and b) alluvial mining process. Note: Inventory data from: GLO: Global, RoW: Rest-of-World, CO: Colombia [37]. 


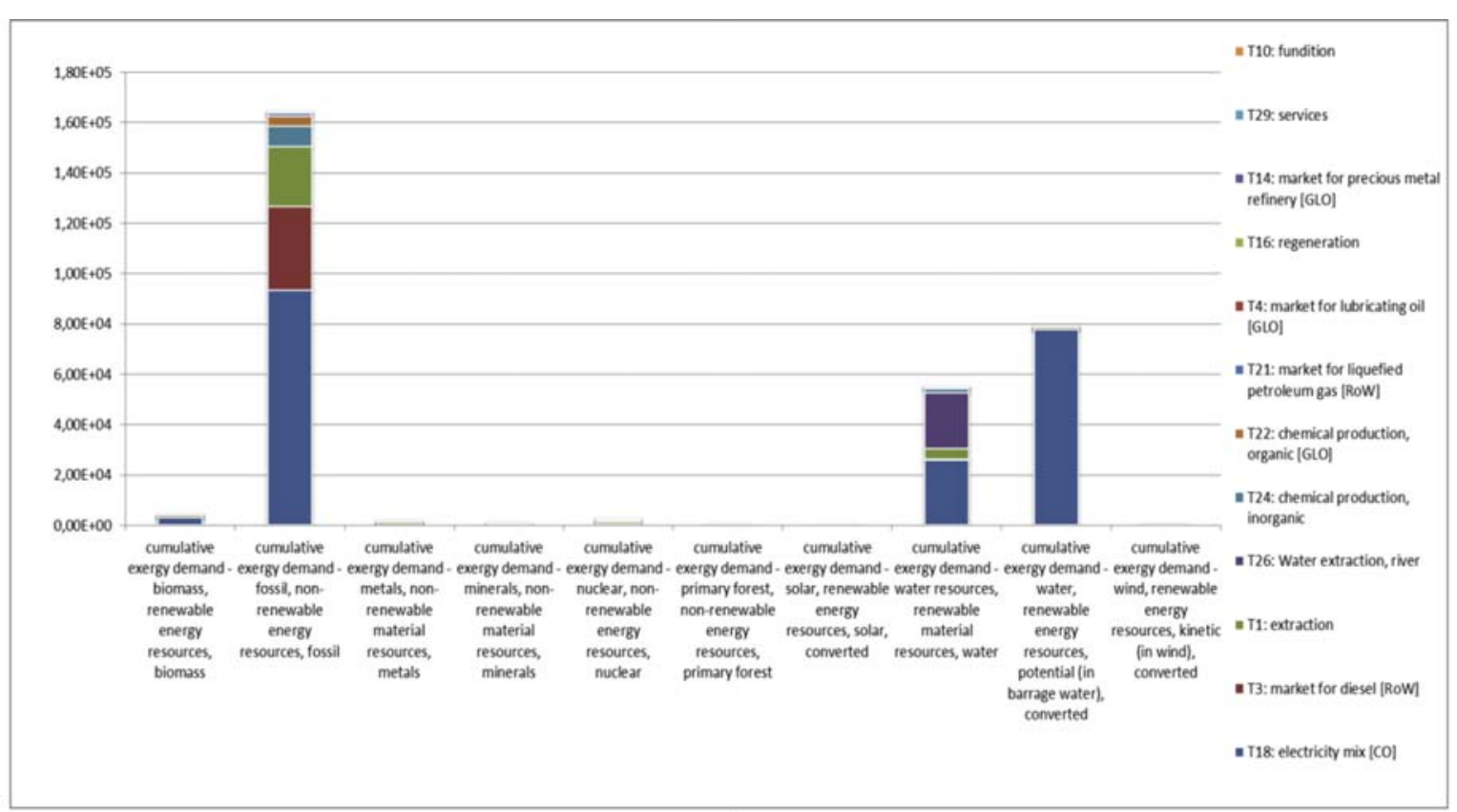

a)

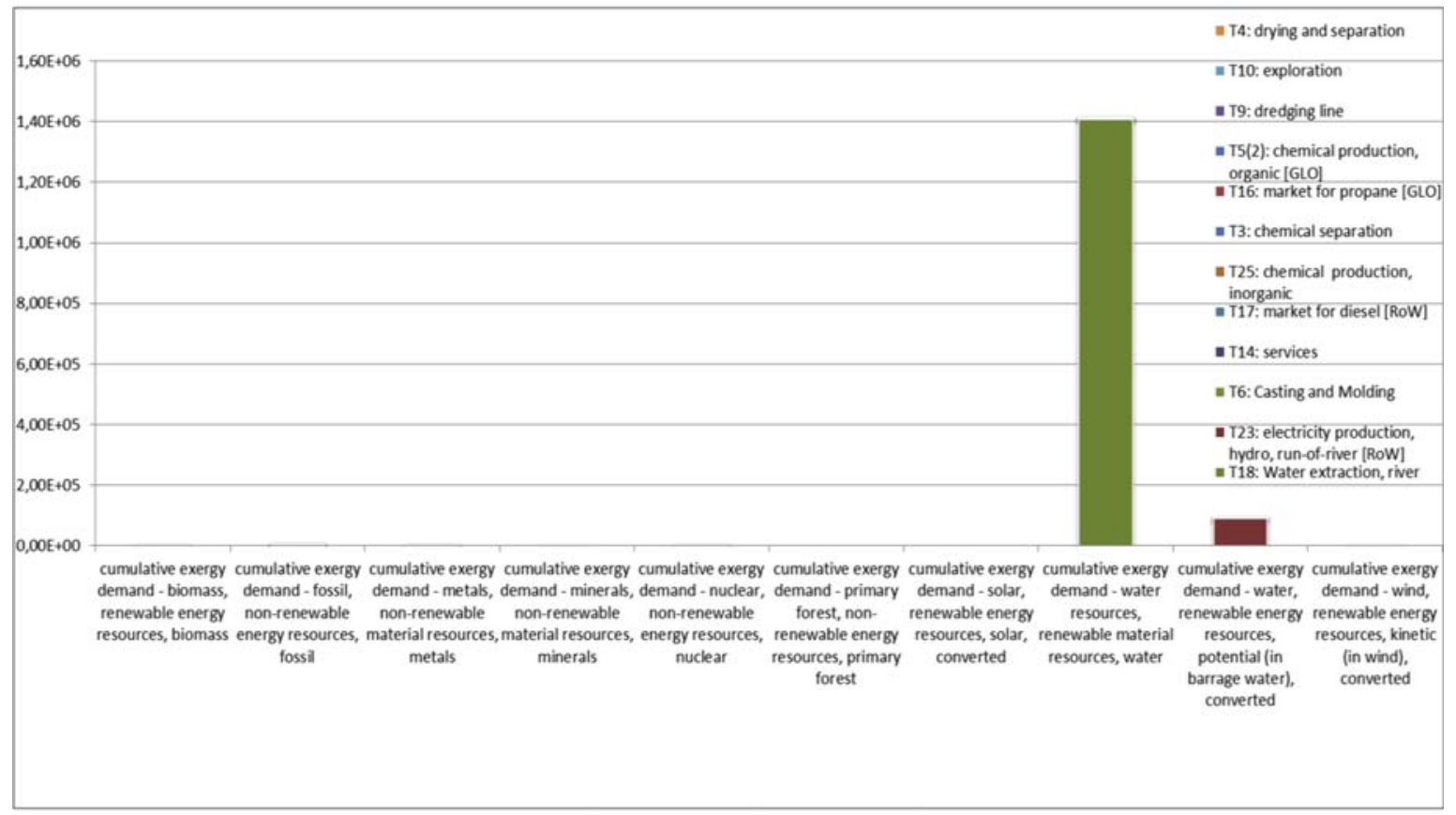

b)

Fig. 4. Cumulative Exergy Demand (CExD) for each stage of a) open-pit mining process and b) alluvial mining process. Note: Inventory data from: GLO: Global, RoW: Rest-of-World, CO: Colombia [37].

\section{Results}

This section addresses the Cumulative Energy Demand (CEnD) and Cumulated Exergy Demand (CExD) indicators from Life Cycle Assessment Perspective. Economic allocation was carried out under economic value conditions; for open-pit 
Table 2. Cumulative energy demand (CEnD) impact assessment method as implemented in Ecoinvent [37].

\begin{tabular}{lll}
\hline & Subcategory & Includes \\
\hline Non-renewable resources & Fossil & hard coal, lignite, crude oil, natural gas, coal mining off-gas, peat \\
& Nuclear & uranium \\
& Primary forest & wood and biomass from primary forests \\
Renewable resources & Biomass & wood, food products, biomass from agriculture, eg straw \\
& Wind & wind energy \\
Solar & solar energy (used for heat \& electricity) \\
& Geothermal & geothermal energy (shallow: 100-300m) \\
& Water & run-of-river hydro power, reservoir hydro power
\end{tabular}

Since both the price and the production (mass) of iron in alluvial mining is not significant compared to gold ore (with average selling price of iron ore equal to $€ 3,00 \mathrm{E}-05$ per gram), the economic allocation was not considered in this system. For this reason, in an open-pit mining process, results under this approach are taken only for gold production, in order to make a more objective comparison between both productive systems.

Due to the lack of LCI data for the Colombian electrical matrix, the electricity mix process for Colombia has been designed, where it took energy average (2012-2016) for different energetic resources: hydraulic $(70.4 \%)$, gas $(15.2 \%)$, coal $(8.41 \%)$, wind $(0.10 \%)$, biomass $(0.70 \%)$, fuel oil $(0.66 \%)$, Gas Jet-A1 mix (1.75\%), ACPM (2.70\%), JET-A1 (0.04\%), others $(0.09 \%)$ [38].

\subsection{Cumulative Energy Demand (CEnD)}

Fig. 3 ( $a$ and $b$ ) present the CEnD contribution for renewable and non-renewable resources of open-pit and alluvial mining process phases (input materials, mining, mine operation, refining and smelting), respectively. In both mining systems, the highest energy consumption is presented in input materials phase, followed by the extraction phase.

The total CEnD in open-pit mining technology for gold production is equal to $2.51 \times 1005 \mathrm{MJ}$-eq. The greatest contribution to energetic process comes from fossil energy resource and water resource for hydroelectric generation, with a value equal to $1.65 \times 1005$ MJ-eq $(65.88 \%$ of the total $)$ and $7.89 \times 1004 \mathrm{MJ}-\mathrm{eq}(31.42 \%$ of the total), respectively. $57.30 \%$ of the fossil energy is consumed in electricity mix for Colombia (consumed in greater proportion in the grinding mill process), followed by market for diesel $(19.81 \%)$, extraction process $(14.44 \%)$, organic and inorganic chemical production $(7.44 \%)$ and market for liquefied petroleum gas $(0.74 \%)$ (consumed in several mining process services), among the most relevant ones. Likewise, $98.54 \%$ of the energy content of water used for hydroelectric generation corresponds to the electricity mix generation for Colombia, followed by extraction process $(1.10 \%)$. The $80.89 \%$ of the cumulative energy demand comes from gold production $(2.51 \times 1005 \mathrm{MJ}-$ eq), $17.86 \%(5.54 \times 1004 \mathrm{MJ}-\mathrm{eq})$ of stocked material and $1.25 \%(3.89 \times 1003 \mathrm{MJ}$-eq) of silver for a cumulative total exergy demand equal to $3.75 \times 1005 \mathrm{MJ}-$ eq.

For alluvial mining technology, the total CEnD is equal to $9.12 \times 1004 \mathrm{MJ}-\mathrm{eq}$, the largest energetic contribution comes from water potential energy and fossil resource with a value equal to $8.93 \times 1004 \mathrm{MJ}-$ eq $(97.83 \%$ of the total) and $1.80 \times 1003 \mathrm{MJ}$-eq $(1.97 \%$ of the total), respectively. $99.98 \%$ of water energy potential is consumed in electricity production

Table 3. Cumulative exergy demand (CExD) impact assessment method as implemented in Ecoinvent [37].

\begin{tabular}{lll}
\hline & Subcategory & Name \\
\hline Non-renewable resources & Fossil & non-renewable energy resources, fossil \\
& Nuclear & non-renewable energy resources, nuclear \\
& Primary forest & non-renewable energy resources, primary forest \\
& metals & non-renewable material resources, metals \\
menewable resources & minerals & non-renewable material resources, minerals \\
& Biomass & renewable energy resources, biomass \\
& Wind, & renewable energy resources, kinetic (in wind), converted \\
& Water & renewable energy resources, solar, converted \\
& Water & renewable material resources, water \\
& & renewable energy resources, potential (in barrage water), converted \\
\hline
\end{tabular}


(hydro, run-of-river). $53.23 \%$ of fossil energy resource is consumed in electricity production (hydro, run-of-river), followed by services (22.29\%), casting and molding $(10.10 \%)$, market for diesel $(8.74 \%)$ and inorganic chemical production $(4.67 \%)$ stages. Approximately, $100 \%$ of energy resources consumption comes from gold production.

\subsection{Cumulative Exergy Demand (CExD)}

In the same way, Fig. 4 (a and b) present the $\mathrm{Cu}$ mulative Exergy Demand (CExD) to open-pit and alluvial mining technologies respectively, where there is no significant difference with respect to the Cumulative Energy Demand (CEnD), by keeping the same behavior. The total contribution of CExD from gold production, in open-pit mining is equal to $3.07 \times 1005 \mathrm{MJ}-\mathrm{eq}$; the greatest contribution is given by the consumption of fossil, non-renewable energy resources with a value equal to $1.64 \times 1005 \mathrm{MJ}$-eq ( $53 \%$ of the total), production which is distributed as follows: electricity mix for Colombia $(56.84 \%)$, market for diesel $(20.20 \%)$, extraction $(14.57 \%)$, organic and inorganic chemical production $(7.39 \%)$ and market for liquefied petroleum gas $(0.75 \%)$ among the most representative ones. CExD attributable to hydroelectricity generation is equal to $7.89 \times 1004$ MJ-eq ( $26 \%$ of total), where $98.54 \%$ corresponds to electricity mix for Colombia. The water resource, used in different stages of the mining process also has a significant exergy contribution, with a value equal to $5.49 \times 1004 \mathrm{MJ}$-eq $(18 \%$ of the total), where $47.01 \%$ comes from electricity mix for Colombia and $40.03 \%$, comes from water extracted from rivers (used in different stages of the process, which presents the highest consumption, in the primary crushing process) and $7.82 \%$ used in the extraction process.

It is worth mentioning that $81.77 \%$ of the Cumulative Demand for Exergy comes from gold production $(3.07 \times 1005 \mathrm{MJ}-\mathrm{eq}), 16.96 \%(6.36 \times 1004 \mathrm{MJ}-$ eq) of stocked material and 1.27\% $(4.75 \times 1003 \mathrm{MJ}-$ eq) of silver for a Cumulative Total Exergy Demand equals to $3.75 \times 1005 \mathrm{MJ}$-eq.

Total CExD in alluvial mining technology was equal to $1.50 \mathrm{E}+06 \mathrm{MJ}$-eq as expected because water resource presents the greatest exergy contribution, being the critical input resource with a value equal to $1.41 \times 1006 \mathrm{MJ}$-eq. This significant contribution of $93.84 \%$ occurs mainly in the extraction phase (the Trommel process), which is followed by water resource used in electrical generation (run-ofriver power plant) with a value equal to $8.92 \times 1004$ MJ-eq $(6.04 \%)$. Approximately, $100 \%$ of the total CExD, comes from gold production. Finally, Fig. 5,
Table 4 and Table 5 summarize the comparison between CEnD and CExD indicators for open-pit and alluvial mining systems.

\subsection{Sensitivity analysis of Cumulative Energy/ Exergy Demand}

Sensitivity analysis is generally used to test system response to changed input variable(s), by evaluating the resulting output variable(s) change for plausibility. Also, the influence of a certain change in a system input or efficiency on a certain output results may be examined [39].

In the presented model scenarios of fuel and electric energy efficiency were defined to analyze the changes in results for changed efficiency levels. Compared to the base open pit and alluvial models, models with electricity and fuel efficiency improvements of $10 \%, 20 \%$ and $30 \%$ in the foreground system were evaluated as shown Fig. 6. The scenarios were created, by applying a consumption factor to all processes, which consume either fuel (diesel) or electricity, and vary this consumption factor for diesel (CFD) or for electricity (CFE) from 1.0 to 0.7 . Thereby, by increasing respective efficiency up to $30 \%$. As a result, indictors of the cumulated exergy demand (CExD) method were chosen. The significant categories in CExD resulted to be exergy demand in the form of fossil fuels, water resources, and potential energy.

As can be seen in Fig. 3, the increased efficiency and therefore, lower diesel consumption resulted in insignificant changes in water resources and potential energy/exergy demand. The fossil fuel exergy demand decreased about $6 \%$ in open-pit mining and $2.6 \%$ in alluvial mining, which can be explained by high fossil fuel exergy demand of the background system like grid energy or transportation.

The lower electricity consumption achieved by higher efficiency resulted in both systems in a nearly proportional decrease of potential energy exergy demand, as both systems use hydropower, open-pit mining from the Colombian electricity grid and alluvial mining from a specific run-of-river generation. As the run-of-river plant may be considered to consume less water resources than the mainly dam-based generation of the national grid, the exergy demand of water resources only diminishes in the open-pit scenario, and it shows nearly no change in the alluvial scenario. The decrease of fossil fuel exergy demand, in open-pit mining stems from the nearly $30 \%$ portion of electricity generation based on coal, gas, and oil, whereas, the similar decrease on a percentage basis of fossil fuel demand in the alluvial systems only 


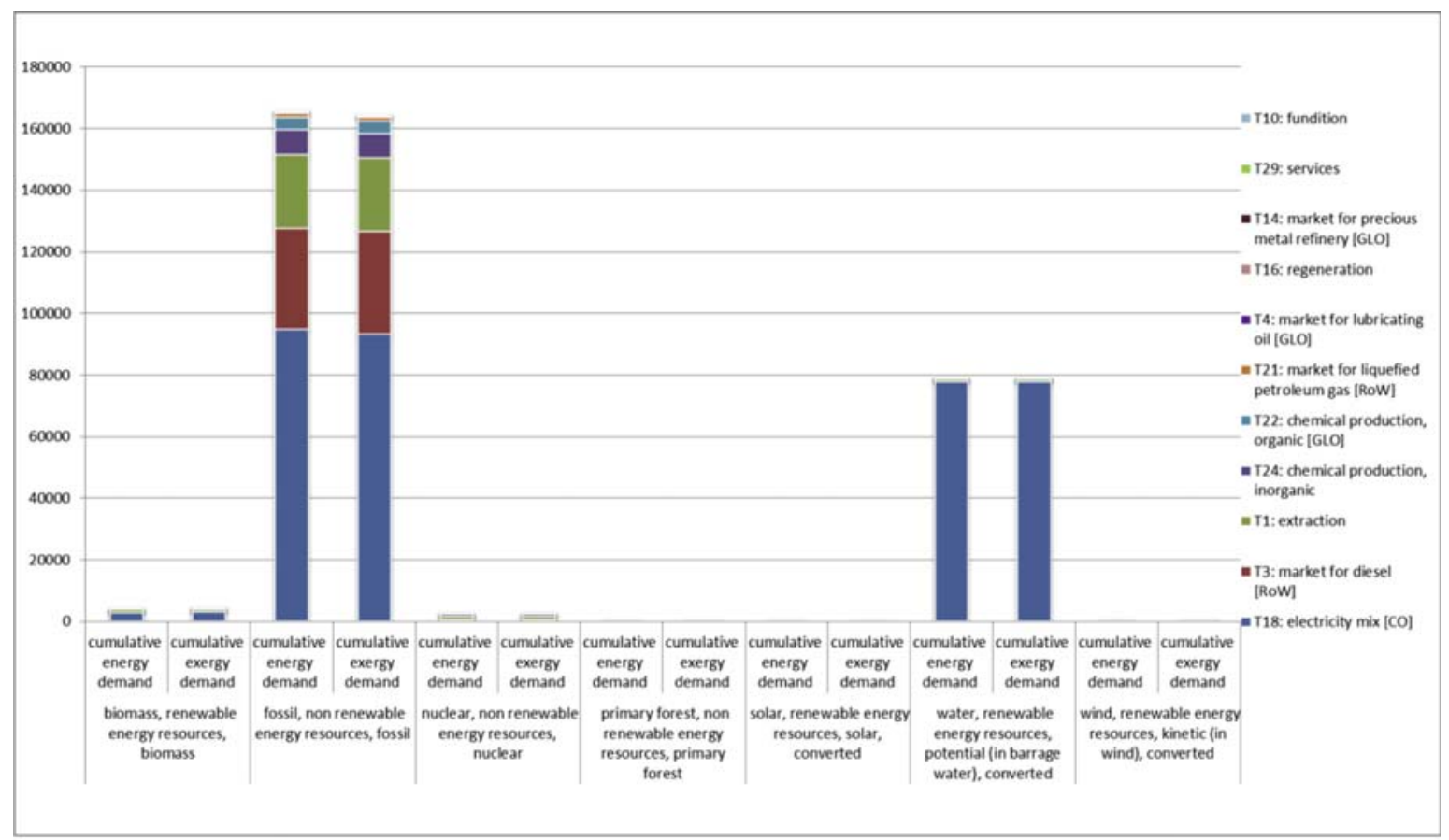

a)

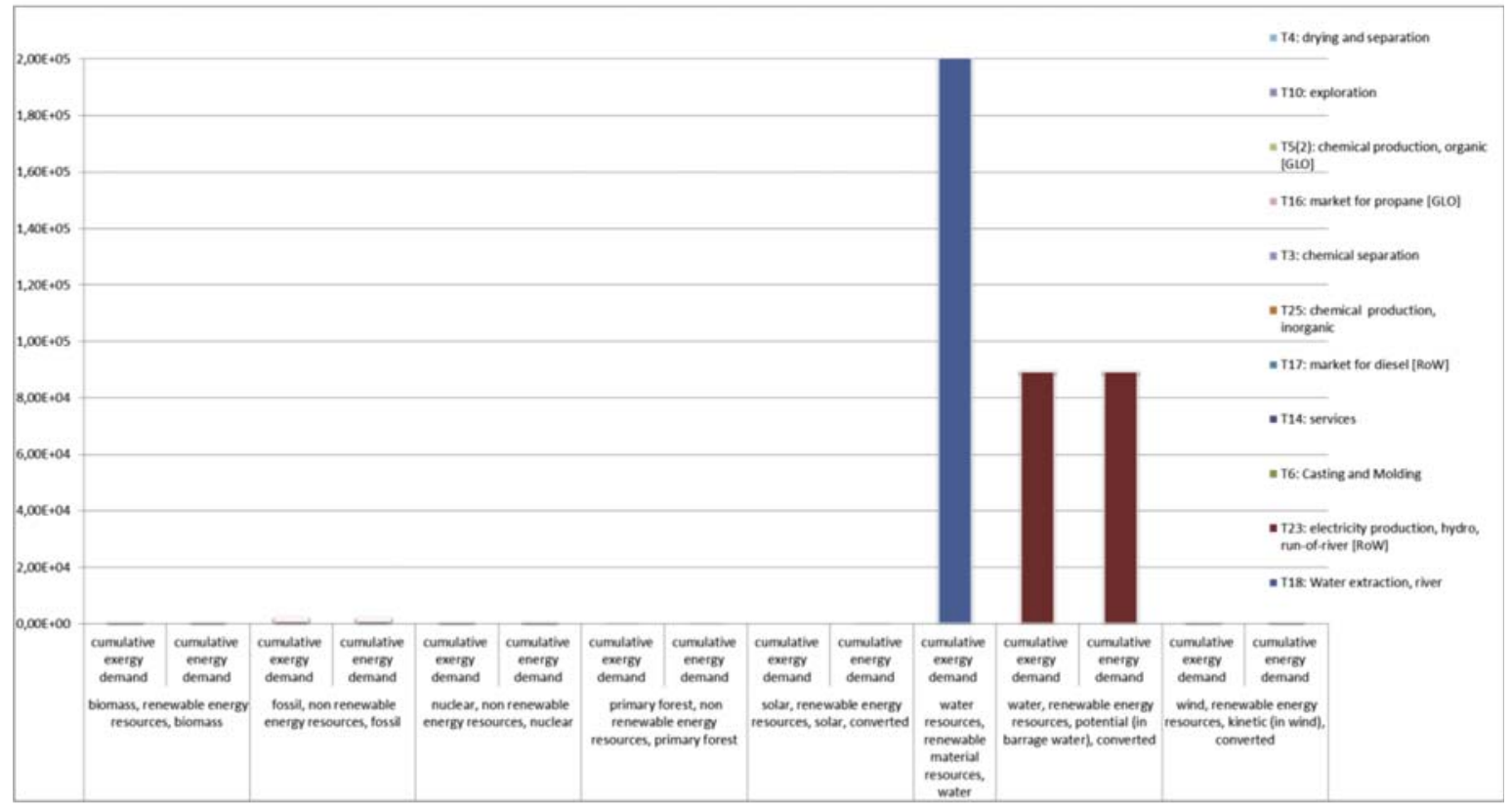

b)

Fig. 5. Comparison between $C E n D$ and $C E x D$ for each stage of a) open-pit mining process and $b$ ) alluvial mining process. Note: Inventory data from: GLO: Global, RoW: Rest-of-World, CO: Colombia [37].

represents about $1 \%$ of the total value of the potential energy/exergy demand, which may be explained by the maintenance and other service processes of the run-of-river plant, which uses average electricity grid mixes.

\section{Conclusions}

Through the present study, it was possible to see the limitations of Traditional Exergy Analysis System, by incorporating the Life Cycle Assessment as a complementary and not exchangeable analysis, it 


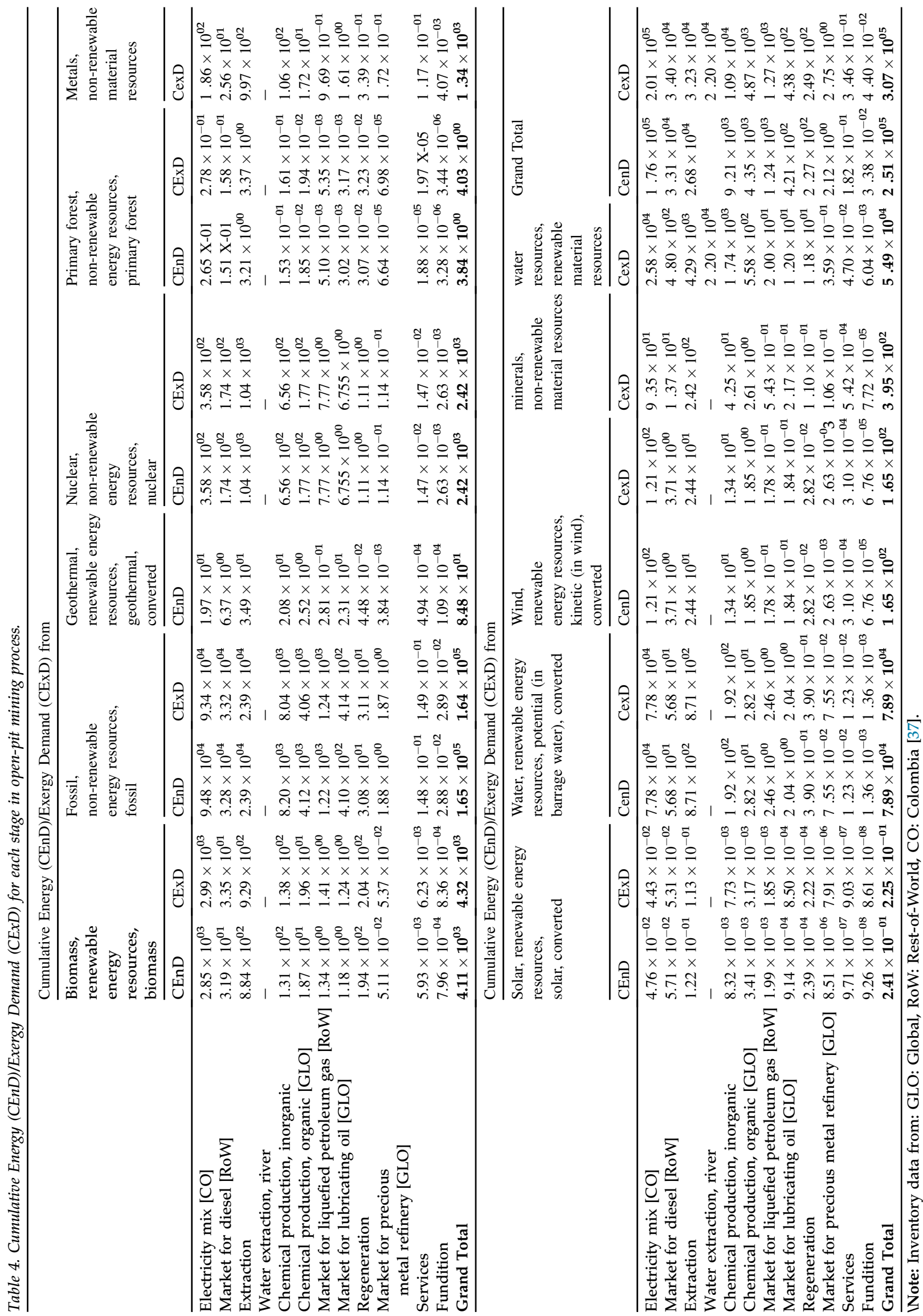




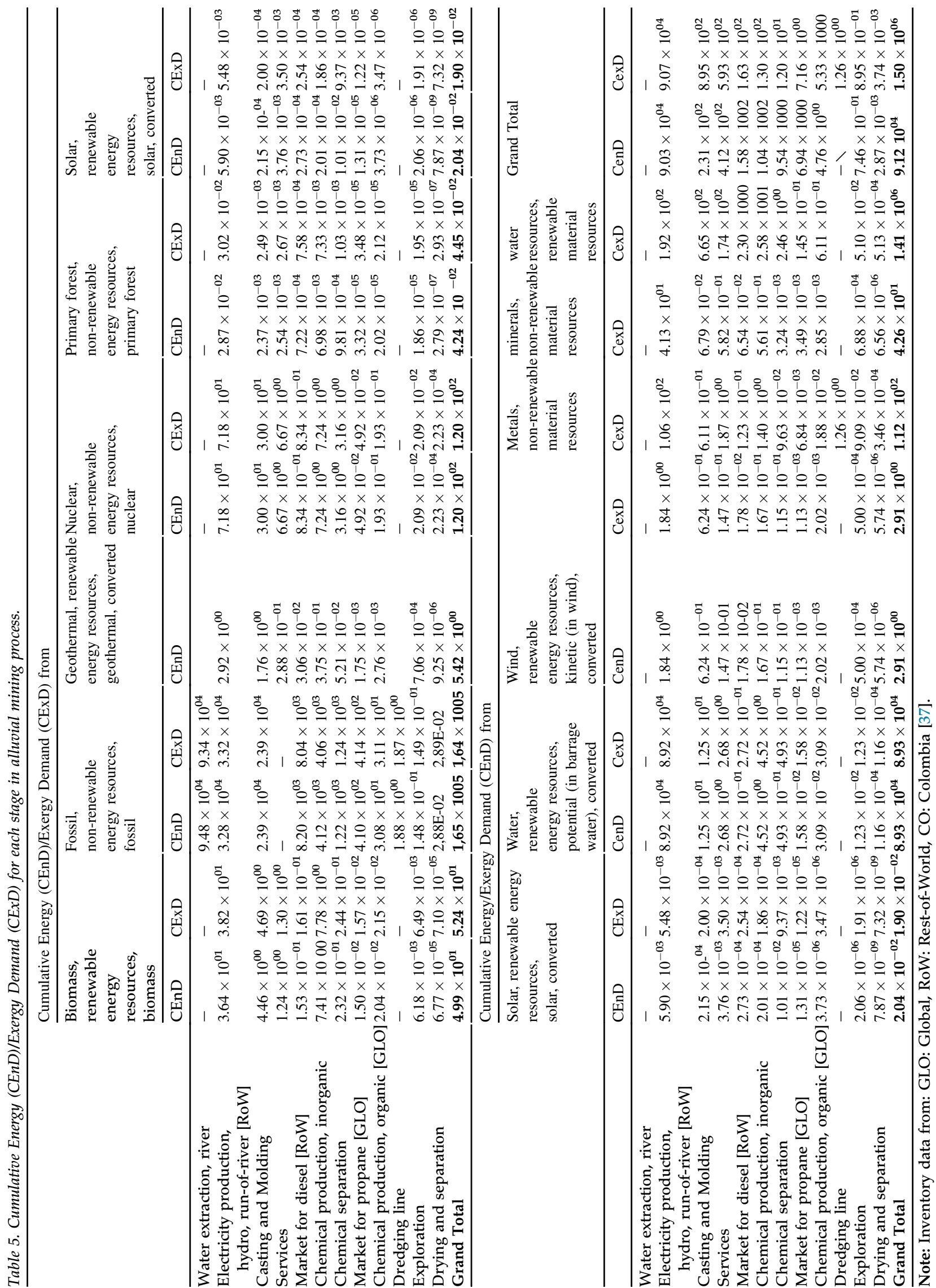




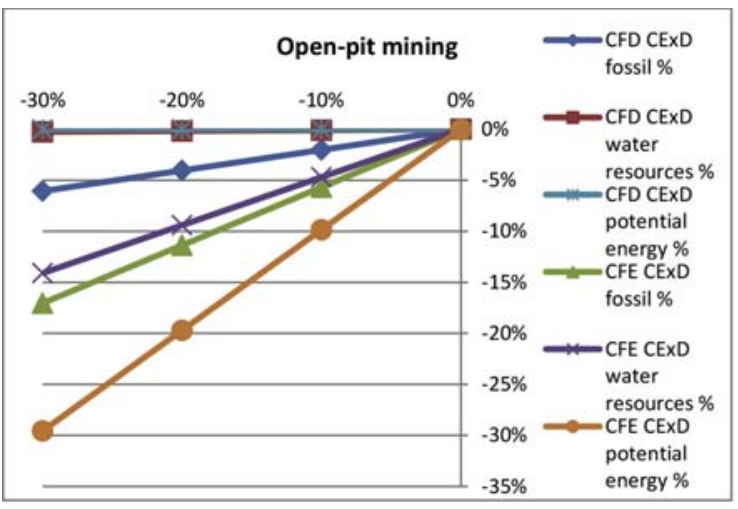

a)

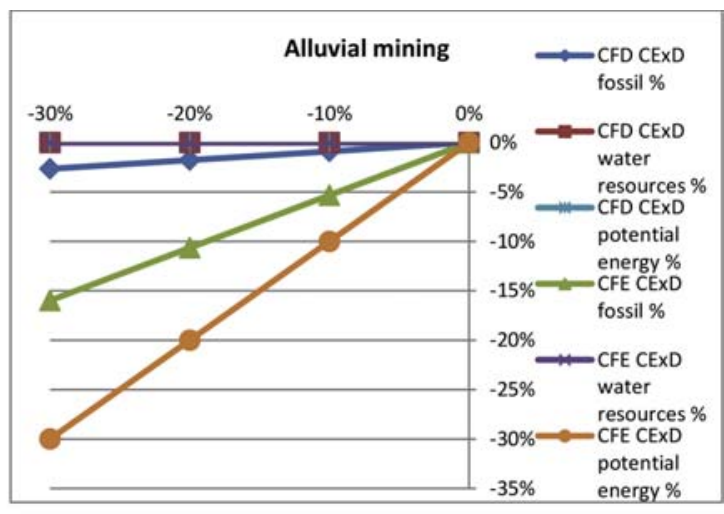

b)

Fig. 6. CExD sensitivity analysis for a) open-pit mining technology b) alluvial mining technology.

was possible to quantify the energy and exergy used throughout gold life cycle, by distinguishing between renewable and non-renewable energy and exergy requirements under the LCA perspective. Thermodynamic approach allows to examine the most efficient way of carrying out two mining processes from cradle to gate, by allowing to quantify energy quality losses within the process, but this analysis cannot indicate how the process can be improved, but it can indicate where the process may be improved and, in turn, it might receive technical attention [40].

For the open-pit mining process, $65.74 \%$ of the energy consumed comes from fossil (non-renewable) resource, and $31.43 \%$ comes from the use of potential energy of water (renewable resource). Unlike the alluvial mining process, where $97.92 \%$ comes from the use of water as an energy resource, and only $1.97 \%$ comes from fossil energy. This is because in alluvial mining, electricity used is generated by run-of-the-river power plants, which do not require reservoirs and thus, there exist minimal environmental impact.

In exergy terms, in open-pit mining, $53 \%$ of exergy consumed comes from fossil energy and $26 \%$ of energetic use of water. This is because usable energy content of each energy resource is not $100 \%$. On the other hand, in alluvial mining, $94 \%$ of exergy flow comes from water as a resource used within process activities. This is because of the role water played in the beneficiation process and gold obtained in alluvial mining extractive process. Approximately, the remaining 6\% comes from the use of potential energy of water for the generation of electricity, which satisfies $100 \%$ of electricity consumption of the extractive process, and other activities of the company.
The effect of increased efficiency in diesel and electricity consumption in the open-pit process was analyzed in a sensitivity analysis of Cumulated Exergy Demand (CExD) indicators, by simulating foreground process efficiency gains of up to $30 \%$ for diesel and for electricity consumption. The consumption of $30 \%$ less diesel in the mining processes did only result in $6 \%$ and $2.6 \%$ decrease of overall fossil CExD in the open-pit process and in alluvial mining, respectively, which shows a strong dependency on fossil exergy sources in background processes. The reduction of $30 \%$ of the electricity consumption, however led to a nearly completely proportional decrease of renewable potential energy CExD in both systems.

In order to reduce the environmental impact associated with gold mining life cycle, from cradle to gate, for the two extractive systems described in this study, four strategies are proposed:

- Increased efficiency by reducing the exergy required in tails and extraction stages in openpit mining process and in the casting and molding stage in alluvial mining, where large exergy supplies are required.

- Increasing efficiency through the reduction of exergy emissions and residues in smelting and molding stages in alluvial mining, and stripping stage in the open-pit mining.

- Using external exergy resources, such as renewable energy resources (solar, wind, hydraulic) instead of diesel or grid energy, as the processes, which use rather renewable resources instead of non-renewable resources, which are more sustainable.

- Applying the concept of circular economy by maximizing the cycled use of all involved 
resources which implies the reduction of environmental impacts in two ways:

1) By reducing exergy wasted, which is contained in usable waste released into the environment, since the rate of polluting emissions should not exceed the corresponding assimilation capacity of the environment.

2) By reducing the use of virgin resources within the process, rather reusing resources since the rate of use of non-renewable resources must not exceed the rates at which renewable substitutes are developed.

The above can look reflected in management strategies for water and energy consumption and removed mining material, which should be implemented to reduce renewable and non-renewable inputs and, in turn, improve the environmental quality. In fact, regarding water use management, in open-pit mining the $83,98 \%$ of water is reused into the process and, in alluvial mining the $24,65 \%$ of water return to the same catchment area, despite water intensity of the wet process [36]. It would be possible to increase the energy efficiency presented in each stage of the process by environmental decision making related with improving the technology adopted, mainly in those with highest consumptions (grinding mill and extraction stages in open-pit mining technology; stripping and dredging line stage in alluvial mining technology) and losses (extraction and services stage in open-pit mining; exploration and services stage in alluvial mining).

Another strategy is the extraction of minerals deposits implies a reduction of the natural stock, which lead to declining ore grades and a tendency to excavate deeper and deeper into the crust, and more commercially worthless material needs to be removed to obtain the same amount of ore than before. In turn huge amounts of water and energy are required to extract minerals as it happens with fossil fuels. A possible alternative approach could be a reprocessing of tailings material to extract precious metals that ended up in tails slurry or to remove toxic substances.

\section{Conflicts of interest}

None declared.

\section{Ethical statement}

Authors state that the research was conducted according to ethical standards.

\section{Funding body}

This project was carried out as part of the Doctoral Program funded by the Department of Science and Technology of Colombia (COLCIENCIAS).

\section{Acknowledgments}

This project was carried out as part of the Doctoral Program funded by the Department of Science and Technology of Colombia (COLCIENCIAS). The authors thank the mining companies (open-pit and alluvial mining technology) for the provided data and recommendations. This research was supported by the 1) School of Mines at the National University of Colombia at Medellín; 2) Bioprocess and Reactive Flow Research Group; 3) Faculty of Applied sciences, Department of Biotechnology at Delft University of Technology; 4) Biotechnology and Society Research Group.

\section{References}

[1] ICMM. Our Work: Sustainable Development Framework. International Council on Mining and Metals; 2012. ”.

[2] Mancini L, Benini L, Sala S. Resource Footprint of Europe: Complementarity of Material Flow Analysis and Life Cycle Assessment for Policy Support. Environmental Science and Policy 2015;54.

[3] UNEP. Responsible Resource Management for a Sustainable World: Findings International Resource Panel. 2012.

[4] WBCSD. Eco-Efficiency: Creating More Value with Less Impact. WBCSD; 2000.

[5] Dincer I, Rosen MA. Exergy, Energy, Environment and Sustainable Development. 1a. Ed. Elsevier; 2007.

[6] Kharrazi A, Kraines S, Lan H, Yarime M. Advancing Quantification Methods of Sustainability: A Critical Examination Emergy, Exergy, Ecological Footprint, and Ecological Information-Based Approaches. Ecological Indicators 2014; 37(PART A):81-9.

[7] Fonseca A, McAllister ML, Fitzpatrick P. Measuring What? A Comparative Anatomy of Five Mining Sustainability Frameworks. Minerals Engineering 2013:46-7.

[8] Neumayer E. Weak Versus Strong Sustainability: Exploring the Limits of Two Opposing Paradigms. third ed. Cheltenham, UK: Edward Elgar; 2010.

[9] Tuusjärvi M. From a Mine to You: Sustainability of the Finnish Mining Sector in the Context of Global Supply Chains of Metals. 2013.

[10] Young J, Septoff A. Digging for Change: Towards a Responsible Minerals Future. An NGO and Community Perspective. " Mineral Policy Centre; 2002.

[11] Lazarevic D, Buclet N, Brandt NJ. The Application of Life Cycle Thinking in the Context of European Waste Policy. Cleaner Production 2012;29(30):199-207.

[12] Finnveden G, Arushanyan Y, Brandao M. Exergy as a Measure of Resource Use in Life Cycle Assessment and Other Sustainability Assessment Tools. "RESOURCES-BASEL; 2016.

[13] Awuah-offei K, Adekpedjou A. Application of Life Cycle Assessment in the Mining Industry. 2011. p. 82-9.

[14] Dincer I, Rosen MA. Exergy Analysis of Heating, Refrigerating and Air Conditioning. Methods and Applications Chapter 1 - Exergy and Its Ties to the Environment, Economics, and Sustainability. 2015. 
[15] Niembro I, Gonzalez M. "Energía y Exergía : Enfoques Hacia La Sostenibilidad Mediante El Análisis de Ciclo de Vida. Congreso Nacional del Medio Ambiente. 2012.

[16] Ayres RU, Ayres LW, Martinas K. Exergy, Waste Accounting and Life-Cycle Analysis. Energy 1998;23:355-63.

[17] Dewulf J, et al. Cumulative Exergy Extraction from the Natural Environment (CEENE): A Comprehensive Life Cycle Impact Assessment Method for Resource Accounting. " Environmental Science and Technology; 2007.

[18] Domínguez A, Valero A, Valero A. Exergy Accounting Applied to Metallurgical Systems: The Case of Nickel Processing. Energy 2013;62:37-45.

[19] Finnveden G, Östlund P. Exergies of Natural Resources in Life-Cycle Assessment and Other Applications. Energy 1997; 22(9):923-31.

[20] Gössling-Reisemann S. Combining LCA with Thermodynamics. In: Marx Gomez C, J, Sonnenschein M, Müller M, Welsch H, Rautenstrauch, editors. Information Technologies in Environmental Engineering. Springer; 2007. Heidelberg, Germany.

[21] Zah R, Böni H, Gauch M, Hischier R, Lehmann M, Wäger P. Life Cycle Assessment of Energy Products: Environmental Assessment of Biofuels. EMPA; 2007.

[22] Benetto E, Dujet C, Rousseaux P. Possibility Theory: A New Approach to Uncertainty Analysis? The International Journal of Life Cycle Assessment 2006;11(2):114-6.

[23] Maes D, Van Passel S. Advantages and Limitations of Exergy Indicators to Assess Sustainability of Bioenergy and Biobased Materials. Environmental Impact Assessment Review 2014.

[24] Carmona G, Luis KW, Valero A, Valero A. Colombian Mineral Resources: An Analysis from a Thermodynamic Second Law Perspective. Resources Policy 2015;45:23-8.

[25] Corneliessen RL. Thermodynamics and Sustainable Development. The Use of Exergy Analysis and the Reduction of Irreversibility. "Univ. of Twente; 1997.

[26] Portha JF, Louret S, Pons MN, Jaubert JN. Estimation of the Environmental Impact of a Petrochemical Process Using Coupled LCA and Exergy Analysis. Resources, Conservation and Recycling 2010;54(5):291-8.

[27] Rocco MV, Di Lucchio A, Colombo E. Exergy Life Cycle Assessment of Electricity Production from Waste-to-Energy Technology: A Hybrid Input-Output Approach. Applied Energy 2017;194:832-44.

[28] Rubio Rodríguez MA, De Ruyck J, Díaz PR, Verma VK, Bram S. An LCA Based Indicator for Evaluation of Alternative Energy Routes. Applied Energy 2011;88:630-5.
[29] Luu LQ, Halog A. Sustainability in the Design, Synthesis and Analysis of Chemical Engineering Processes Life Cycle Sustainability Assessment: A Holistic Evaluation of Social, Economic, and Environmental Impacts. 2016.

[30] De Meester B, Jo D, Arnold J, Van Langenhove H. An Improved Calculation of the Exergy of Natural Resources for Exergetic Life Cycle Assessment (ELCA). Environ. Sci. Technol 2006; 40(21):6844-51.

[31] Bösch ME, Hellweg S, Huijbregts M, Frischknecht R. Applying Cumulative Exergy Demand (CExD) Indicators to the Ecoinvent Database. International Journal of Life Cycle Assessment 2007;12:181-90.

[32] UNDP. United Nations Development Programme. Human Development Reports. 2016.

[33] CIPRO. Redescubriendo La Minería Aurifera Aluvial. Colombia: Bogotá; 2014.

[34] Cano LNA, Velásquez HI, McIntyre N. Comparing the Environmental Sustainability of Two Gold Production Methods Using Integrated Emergy and Life Cycle Assessment. Ecological Indicators 2019;107:105600.

[35] Cano N. Sustainability Assessment of Alluvial and Open Pit Mining Systems in Colombia: Life Cycle Assessment, Exergy Analysis, and Emergy Accounting. "Universidad Nacional de Colombia; 2018.

[36] Cano N, Osorio J, García F, Franco I. SDG 6 Clean Water and Sanitation: Sustainable Use of Energy and Water Resources in the Mining Sector: A Comparative Case Study of Open-Pit and Alluvial Mining Technology. In: Franco Isabel B, Derbyshire Ellen, Chatterji Tathagata, Tracey James, editors. Actioning the Global Goals for Local Impact Towards Sustainability Science, Policy, Education and Practice. Singapore: Springer Nature Singapore; 2019. p. 85-104.

[37] Hischier R, et al. Implementation of Life Cycle Impact Assessment Methods Data v2.2. ecoinvent Report No. 2010; 3(3):176. 2010.

[38] Ministry of Mines and Energy. Política Mínera de Colombia Bases Para La Minería Del Futuro, ”; 2016. p. 62.

[39] Babic A, et al. Overall Bias Methods and Their Use in Sensitivity Analysis of Cochrane Reviews Were Not Consistent. Journal of Clinical Epidemiology Journal Pr 2019.

[40] Szargut J, Morris DR, Steward FR. Exergy Analysis of Thermal, Chemical and Metallurgical Processes. New York, NY, USA: Hemisphere; 1988. 